\title{
Analisis Faktor-Faktor Penghambat Membaca Permulaan pada Siswa Kelas 1 SD
}

\section{Fitria Pramesti ${ }^{1 *}$}

\author{
A R T I C L E I N F O \\ Article history: \\ Received 20 May 2018 \\ Received in revised form \\ 5 June 2018 \\ Accepted 18 July 2018 \\ Available online 23 August \\ 2018 \\ Kata Kunci: \\ Faktor penghambat, \\ Membaca Permulaan, \\ Siswa kelas 1 \\ Keywords: \\ Inhibiting factors, \\ Reading Beginning, \\ Grade 1 students
}

\begin{abstract}
A B S T R A K
Penelitian ini bertujuan untuk menganalisis faktor-faktor penghambat membaca permulaan pada siswa kelas 1 SD Negeri 1 Wonorejo dan alternatif solusi yang dapat digunakan untuk mengatasi kesulitan dalam membaca permulaan.Metode penelitian ini merupakan jenis penelitian kualitatif dengan menggunakan pendekatan studi kasus. Instrumen yang digunakan berupa lembar observasi guru, lembar observasi siswa, dan pedoman wawancara.Teknik pengumpulan data yang digunakan adalah observasi, wawancara, dan dokumentasi.Analisis data menggunakan reduksi data, penyajian data, dan penarikan kesimpulan. Hasil penelitian menunjukkan bahwa faktorfaktor penghambat membaca permulaan pada siswa kelas 1 SD Negeri 1 Wonorejo diantaranya yaitu: 1). Faktor Intelektual, 2). Faktor lingkungan, 3). Kurangnya motivasi dari pihak keluarga 4). Kurangnya minat membaca siswa yang rendah. Sedangkan alternatif solusi yang dapat digunakan untuk mengatasi kesulitan dalam membaca permulaan yaitu : 1). Guru kelas lebih memprioritaskan anak-anak yang mengalami
\end{abstract} kesulitan, 2). Guru kelas juga harus memberikan perhatian khusus kepada anak-anak yang mengalami kesulitan, 3). Hubungan kerjasama yang baik antara guru kelas dan orang tua siswa 4). Orang tua harus lebih memperhatikan, memantau anak dalam belajar membaca, 5). Minat siswa harus dikembangkan dan dilatih terus menerus. Hasil penelitian ini dapat digunakan sebagai perbaikan dan untuk meningkatkan kualitas pembelajaran yang dapat mengembangkan minat dan kemampuan siswa kelas rendah dalam keterampilan membaca.Penelitian ini diharapkan dapat memberikan kontribusi berupa pemikiran guna kemajuan kemampuan dalam pembelajaran membaca permulaan bagi siswa kelas 1 .

\section{A B S T RA C T}

This study aims to analyze inhibiting factors of early reading in grade 1 students of SD Negeri 1 Wonorejo and alternative solutions that can be used to overcome difficulties in reading the beginning. This research method is a type of qualitative research using case study approach. The instruments used were teacher observation sheets, student observation sheets, and interview guidelines. Data collection techniques used are observation, interview, and documentation. Data analysis uses data reduction, data presentation, and conclusions. The results showed that inhibiting factors of reading the beginning on the students of grade 1 SD Negeri 1 Wonorejo are: 1). Intellectual Factors, 2). Environmental factors, 3). Lack of motivation from family side 4). Lack of low student reading interest. While alternative solutions that can be used to overcome difficulties in reading the beginning are: 1). Class teachers prioritize children who have difficulty, 2). The classroom teacher should also pay special attention to children who have difficulty, 3). Good working relationship between classroom teachers and parents 4). Parents should pay more attention, monitor children in learning to read, 5). Students' interests should be developed and trained continuously. The results of this study can be used as an improvement and to improve the quality of learning that can develop interest and ability of low-grade students in reading skills. This research is expected to contribute in the form of thinking for the advancement of ability in reading learning beginning to grade 1 students.

Copyright (C) Universitas Pendidikan Ganesha. All rights reserved. 


\section{Pendahuluan}

Pendidikan merupakan suatu proses yang sangat penting dalam kelangsungan hidup manusia. Bagi suatu Negara, pendidikan merupakan salah satu modal untuk mencapai kemajuan.Melalui pendidikan diharapkan tercipta generasi baru yang lebih berkualitas dalam mengembangkan kehidupan bangsa.Pendidikan juga berperan penting dalam sistem pertahanan suatu Negara serta daya saing suatu bangsa.

Terutama di Negara-negara berkembang seperti Indonesia yang mempunyai jumlah penduduk yang cukup banyak.Oleh Karena itu, kualitas pendidikan di Indonesia di tingkatkan.Munib ( 2012, hal.79) menjelaskan bahwa " lingkungan pendidikan dapat ditinjau dari aspek pendidikan formal , informal, dan nonformal pada setiap jenjang dan jenis pendidikan“. Pendidikan pada instusi formal yang diakui lembaga pendidikan Negara adalah sesuatu yang wajib dilakukan di Indonesia yaitu Sekolah Dasar (SD) yang di dalamnya ada peran penting dari seorang guru.

Tugas guru di Sekolah Dasar yaitu menyalurkan informasi berupa pengetahuan mengenai suatu mata pelajaran tertentu kepada siswa sebagai penerima informasi. Ketercapaian materi pelajaran tertentu dapat terwujud dengan baik apabila komponen-komponen utama dalam pembelajaran terpenuhi, komponen-komponen tersebut antara lain : Siswa, Guru dan Kurikulum. Menurut Solchan, dkk (2009, hal.45) bahwa "kurikulum adalah program pendidikan yang disediakan oleh sekolah untuk siswa". Kurikulum yang digunakan pada jenjang pendidikan dasar yaitu Kurikulum Tingkat Satuan Pendidikan ( KTSP ) dan Kurikulum 2013 yang mulai sekarang ini diterapkan di setiap sekolah.

Belajar bahasa adalah salah satu kegiatan manusia yang tidak dapat dipisahkan dalam kehidupan khususnya di Sekolah Dasar. Pada tingkat permulaan, siswa Sekolah Dasar akan diberikan pengetahuan tentang calistung (baca,tulis,hitung). Pada kehidupan sehari-hari, kemampuan membaca, menulis, dan berhitung sangat diperlukan.Berkaitan dengan pembelajaran di SD, sebagian peserta didik masuk SD sesudah mengikuti TK dan sebagian tidak pernah masuk TK.

Implementasi kurikulum 2013 SD dalam kegiatan pembelajaran di kelas-kelas Sekolah Dasar sesuai yang diharapkan pemerintah dan masyarakat, sangat ditentukan oleh kondisi dan situasi peserta didik.Salah satunya adalah membaca yang merupakan pengetahuan dasar yang diperoleh di Sekolah Dasar karena membaca memegang peranan penting.HG.Tarigan (1984, hal.1) menyatakan bahwa "keterampilan berbahasa mencakup 4 segi yaitu keterampilan menyimak atau mendengarkan, keterampilan berbicara, keterampilan membaca, dan keterampilan menulis“. Salah satunya kemampuan dasar yang harus dimiliki siswa adalah membaca yang harus segera dikuasai oleh siswa SD karena keterampilan ini secara langsung berkaitan dengan seluruh proses belajar siswa di SD.

Pembelajaran membaca di Sekolah Dasar dilaksanakan sesuai dengan pembedaan antar kelas-kelas awal dan kelas-kelas tinggi.Pembelajaran membaca di kelas-kelas awal disebut membaca permulaan dan dikelas-kelas tinggi disebut membaca lanjut. Pada siswa kelas 1 sekolah dasar membaca permulaan merupakan proses tahapan awal. Siswa memperoleh kemampuan dan menguasai teknik-teknik membaca dan menangkap isi bacaan dengan baik. Putra (2017) menyatakan bahwa "kesiapan membaca individu melibatkan dirinya dan pengalaman belajar di sekolah, dan faktor dari kesiapan membaca yaitu kesiapan fisik, kesiapan psikologis, kesiapan pendidikan dan kesiapan IQ" Paramita (2013) mengatakan bahwa "Kemampuan membaca merupakan salah satu kunci keberhasilan siswa dalam meraih kemajuan karena dengan kemampuan membaca siswa akan lebih mudah, menggali informasi dari berbagai sumber tertulis". Sudiarta (2017) "Kemampuan membaca adalah modal utama anak dalam melanjutkan pendidikan pada jenjang yang lebih tinggi, hal ini dikarenakan sumber belajar yang tersedia sebagian besar terdapat pada buku yang mengharuskan anak untuk dapat membacanya dengan baik untuk memperoleh informasi yang dibutuhkan". "Kegiatan membaca memiliki peran penting untuk menyerap informasi-informasi ataupun ilmu pengetahuan yang disampaikan lewat bahasa tulis" (Sumantri,2017). Menurut Rasna (2010) "Membaca merupakan salah satu kemampuan dasar yang mempunyai sifat strategis sebagai aktivitas yang kompleks dengan mengerahkan sejumlah besar tindakan. Antari (2013) berpendapat bahwa membaca permulaan adalah siswa berawal mula mengenal huruf dan dalam waktu yang cepat dapat membaca. Anantha (2013) "Membaca permulaan yang menjadi acuan adalah membaca merupakan proses recoding dan decoding”.

Oleh karena itu, guru perlu merancang pembelajaran membaca dengan baik sehingga mampu menumbuhkan kebiasaan membaca siswa sebagai suatu yang menyenangkan. Keterampilan membaca siswa diharapkan harus segera dukuasai oleh siswa SD karena keterampilan ini secara langsung berkaitan dengan seluruh proses belajar siswa. Khususnya di kelas rendah atau kelas 1 keberhasilan siswa dalam mengikuti proses kegiatan belajar mengajar di sekolah sangat ditentukan oleh penguasan kemampuan membaca permulaan mereka. 
Siswa mengalami kesulitan dalam menangkap dan memahami informasi yang disajikan melalui berbagai buku pelajaran, buku-buku bahan penunjang.Akibatnya kemampuan belajarnya juga lamban dibanding dengan teman-temannya yang tidak mengalami kesulitan dalam membaca.Hal tersebut didukung dengan penelitian yang berjudul faktor pendukung dan penghambat kemampuan membaca permulaan siswa kelas II SD Keraton Yogyakarta yang telah dilakukan oleh Ardi Wiranata (2016, hal.54) menyimpulkan bahwa "faktor pendukung dalam membaca permulaan yaitu perpustakan di SD yang memadai, dan guru memberi motivasi kepada peserta didik untuk membaca. Sedangkan faktor-faktor penghambat pembelajaran membaca permulaan pada siswa kelas II SD Negeri Kraton Yogyakarta meliputi faktor guru, siswa, dan proses pembelajaran,faktor penghambat membaca permulaan pada siswa kelas II yang berada pada kategori tinggi yaitu pada faktor siswa, sementara itu faktor penghambat dari faktor guru dan proses pembelajaran berada pada kategori sedang “.

Berdasarkan hasil observasi yang dilakukan oleh peneliti di Tahun 2017 pada tanggal 9 Oktober di SD Negeri 1 Wonorejo bahwa aktivitas membaca siswa terbilang kurang. Hal itu dilihat dari beberapa nilai pada semua mata pelajaran yang masih dibawah rata-rata.Berkaitan dengan nilai-nilai siswa yang masih di bawah rata-rata tersebut diakibatkan karena terdapat beberapa siswa yang masih lambat dalam membaca dan mengalami kesulitan dalam membaca. Bahkan ada yang belum mengenal abjad atau huruf dengan lancar sehingga sulit untuk mengikuti proses pembelajaran.

Kemampuan membaca siswa SD Negeri 1 Wonorejo yang berbeda-beda menunjukkan bahwa siswa yang sudah lancar dalam membaca akan mudah untuk mengikuti proses pembelajaran. Sebaliknya siswa yang belum lancar membaca akan sulit mengikuti proses pembelajaran. Hal tersebut dapat mengakibatkan hasil belajar yang diperoleh masih di bawah rata-rata.Selain itu, media dalam pengajaran membaca permulaan belum dimanfaatkan dengan baik.

Berdasarkan permasalahan yang ada peneliti tertarik untuk meneliti tentang apa saja faktor-faktor yang menghambat membaca permulaan di SD Kelas 1. Dari uraian di atas maka peneliti terdorong untuk melakukan penelitian dengan judul " Analisis Faktor-faktor Penghambat Membaca Permulaan Pada Siswa Kelas 1 SD Negeri 1 Wonorejo Kecamatan Sumbergempol Kabupaten Tulungagung Tahun Ajaran 2017/2018 ". Penelitian ini setidaknya dapat mendeskripsikan tentang faktor-faktor yang menghambat membaca permulaan pada siswa SD Kelas 1.

Berdasarkan latar belakang masalah, maka dapat dirumuskan permasalahan, yaitu Apa saja faktorfaktor penghambat membaca permulaan pada siswa kelas 1 dan bagaimana alternatif solusi yang dapat digunakan untuk mengatasi kesulitan dalam membaca permulaan pada siswa kelas 1 SD Negeri 1 Wonorejo ? Maka tujuan penelitian ini adalah untuk mengetahui apa saja faktor-faktor penghambat membaca permulaan pada siswa kelas 1 dan mengetahui bagaimana alternatif solusi yang dapat digunakan untuk mengatasi kesulitan dalam membaca permulaan pada siswa kelas 1 SD Negeri 1 Wonorejo.

Ada dua jenis manfaat yang dapat diperoleh darihasil penelitian ini, yaitu manfaat teoritis dan manfaat praktis. Penelitian akan lebih baik jika tidak hanya bermanfaat bagi peneliti saja, tetapi bermanfaat juga bagi pihak lain. Mengembangkan konsep ilmu pengetahuan yang berguna bagi pendidikan. Konsep atau ilmu pengetahuan tersebut khususnya tentang faktor-faktor yang menghambat membaca permulaan pada Siswa Kelas 1 di Sekolah Dasar. Penelitin ini diharapkan dapat memberikan manfaat (1) Bagi Guru memberikan motivasi kepada guru tentang pentingnya pembelajaran membaca permulaan yang benar bagi siswa. (2) Bagi Sekolah meningkatkan kualitas pembelajaran yang dapat mengembangkan minat dan kemampuan siswa kelas kelas rendah dalam keterampilan membaca.dan (3) Bagi Peneliti menjadi acuan bagi penelitian selanjutnya yang berkaitan dengan pembelajaran membaca permulaan dan menjadi acuan bagi si peneliti untuk nantinya sebelum terjun dan mengajar ke dunia pendidikan.

\section{Metode}

Jenis penelitian yang digunakan dalam penelitian ini adalah penelitian kualitatif dengan pendekatan studi kasus.Pendekatan studi kasus dilakukan untuk memperoleh pengertian yang mendalam mengenai situasi atau makna sesuatu subyek yang diteliti. Penelitian ini lebih mementingkan proses daripada hasil, lebih mementingkan konteks daripada suatu variabel khusus, lebih ditunjukkan untuk menemukan sesuatu daripada kebutuhan konfirmasi. Penelitian ini menganalisis faktor-faktor yang menghambat membaca permulaan pada siswa kelas 1 SD Negeri 1 Wonorejo.

Subyek dalam penelian ini adalah semua siswa kelas 1 SD Negeri 1 Wonorejo dengan jumlah 35 siswa terdiri dari 19 siswa laki-laki dan 16 siswa perempuan. Instrumen utama dalam penelitian ini adalah peneliti sendiri, peneliti bertindak sebagai pengumpul data.Sedangkan instrument pendukung dalam penelitian ini berupa pedoman wawancara dengan subyeknya maupun informan atau guru dan 
orang tua siswa untuk mengetahui faktor-faktor yang menghambat membaca permulaan pada siswa.Lembar observasi secara langsung untuk mendapatkan data penelitian yang baik.Lembar observasi ini berupa lembar observasi guru serta lembar observasi siswa.

Lembar observasi guru digunakan untuk mengetahui proses pembelajaran di kelas dari model pembelajaran, media yang digunakan guru untuk meningkatkan kemampuan membaca siswa, dan lembar observasi siswa digunakan untuk mengetahui aktivitas membaca permulaan siswa pada saat proses pembelajaran di dalam kelas dan mengetahui kemampuan atau kesulitan siswa dalam membaca permulaan. Pada penelitian ini teknik pengumpulan data yang digunakan oleh peneliti adalah observasi, wawancaradalam penelitian ini peneliti menggunakan teknik wawancara semistruktrur dimana wawancara ini bertujuan untuk menemukan permasalahan lebih terbuka dimana pihak yang diajak wawancara diminta pendapat dan ide-idenya., dan dokumentasi.

Analisis data pada penelitian kualitatif dilakukan dengan tahap reduksi data membuang yang tidak perlu dan mengorganisasi data dengan cara sedemikian rupa sehingga kesimpulan final dapat ditarik dan diverifikasi. Penyajian data dilakukan dengan memunculkan dan menunjukkan kumpulan data atau informasi yang sudah terorganisasi dan terkategori yang memungkinkan suatu penarikan kesimpulan atau tindakan. Verifikasi (Penarikan Kesimpulan) Verifikasi atau penarikan kesimpulan pada penelitian ini dilakukan dengan cara membandingkan hasil dari observasi dan hasil wawancara. Dari kegiatan ini dapat ditarik kesimpulan tentang faktor-faktor penghambat membaca permulaan pada siswa kelas $1 \mathrm{SD}$.

Trianggulasi yang digunakan peneliti adalah trianggulasi sumber dan trianggulasi metode.Trianggulasi sumber peneliti menggali informasi dari siswa lalu dilakukann trianggulasi ke guru kelas.Data dari sumber tersebut kemudian dideskripsikan dan dikategorikan antara yang memiliki pandangan berbeda dan pandangan mana yang lebih rinci. Sedangkan trianggulasi metode pada peneltian ini peneliti mengungkapkan data tentang faktor-faktor yang menghambat membaca permulaan siswa kelas 1 SD Negeri 1 Wonorejo dengan teknik wawancara dengan siswa kelas 1, guru kelas, dan orang tua siswa.

\section{Hasil dan Pembahasan}

Hasil Penelitian ini untuk mendapatkan informasi mengenai faktor-faktor penghambat membaca permulaan pada siswa kelas 1 SD Negeri 1 Wonorejo dan untuk mengetahui alternatif solusi untuk mengatasi kesulitan dalam membaca permulaan. Kegiatan Observasi guru dalam proses pembelajaran menujukkan hasik yang baik.

1) Hasil observasi aktivitas siswa kelas 1 dalam proses pembelajaran membaca permulaan dan hasi observasi guru pada saat proses pembelajaran

Kegiatan observasi aktivitas siswa kelas 1 dalam proses pembelajaran membaca permulaan dalam proses pengamatan menunjukkan bahwa siswa kelas 1 di SD Wonorejo yang terdiri dari 35 siswa terdapat 32 siswa yang sudah memiliki keamampuan membaca permulaan yang baik, dan 3 siswa yang mengalami hambatan atau kesulitan dalam membaca permulaan. Observasi guru dilakukan untuk mengetahui bagaimana proses pembelajaran pada saat itu, Proses pembelajaran diawali dengan melakukan apersepsi, menjelaskan materi dan tujuan pembelajaran, guru juga sangat menguasai materi pembelajaran dengan baik. Guru juga menggunakan pendekatan dan strategi pembelajaran yang efektif sehingga pembelajaran juga menarik dan tidak membosankan.Guru juga menggunakan media berupa kartu huruf pada saaat pembelajaran.

2) Hasil Wawancara dengan guru kelas 1 SD Negeri 1 Wonorejo dapat dijelaskan sebagai berikut:

Hasil dari kegiatan wawancara yang dilakukan peneliti dengan guru kelas bahwa perpustakaan di SD tersebut sudah cukup memadai.Hal ini dibuktikan dengan tersedianya buku-buku bacaan yang dapat menunjang kemampuan membaca siswa kelas 1 SD. Karakteristik masing-masing siswa juga berbedabeda. Guru juga memberikan motivasi kepada siswa untuk membaca dan guru juga menggunakan proses pembelajaran yang menarik. Kemampuan membaca permulaan siswa dari 35 siswa terdapat 32 siswa yang kemampuan membacanya baik dan 3 siswa yang masih mengalami kesulitan dalam membaca salah satunya karena kemampuan siswa yang rendah dan sulit untuk mengikuti kegiatan pembelajaran sehingga lambat dibanding dengan teman-temannya.

Guru juga tidak mengalami hambatan dalam pembelajaran membaca permulaan. Minat membaca siswa kelas 1 juga sudah terlihat, dari 3 siswa yang mengalami kesulitan masih ada 2 siswa yang minat membacanya rendah tetapi 1 siswa memiliki minat membaca yang baik hanya saja saat wawancara guru bercerita bahwa karena keadaan ekonomi keluarga yang rendah menyebabkan siswa tersebut memiliki kesulitan dalam membaca dan satu siswa yang mengalami kesulitan dikarenakan ibunya yang sudah meninggal dan ayahnya yang sibuk bekerja sehingga kurangnya perhatian dari orang tua serta orang tua 
yang jarang memantau anaknya sehingga siswa tersebut mengalami kesulitan. Guru juga selalu mendampingi dan membatu siswa yang mengalami hambatan dalam membaca permulaan serta guru selalu menjalin hubungan yang baik dengan orang tua siswa untuk kelancaran belajar anak-anaknya.

3) Hasil Wawancara dengan siswa kelas 1 SD Negeri 1 Wonorejo dapat dijelaskan sebagai berikut:

Hasil dari kegiatan wawancara yang dilakukan peneliti dengan siswa bahwa siswa sudah lancar dalam membaca dan saat ditanya oleh peneliti siswa memiliki minat baca dan tidak mengalami kesulitan dalam membaca serta mereka pernah pergi ke perpustakaan untuk membaca. Tetapi berdasarkan hasil dari wawancara saat ditanya siswa tidak mengalami hambatan apa pun tetapi pada saat peneliti membuktikan dengan memberikan teks bacaan dan menyuruh siswa yang di wawancara untuk membaca ada 3 siswa yang masih menghalami hambatan dalam membaca dan belum lancar dalam membaca.

4) Hasil wawancara dengan orang tua siswa kelas 1 SD Negeri 1 Wonorejo dapat dijelaskan sebagai berikut :

Hasil dari kegiatan wawancara yang dilakukan peneliti dengan siswa bahwa orang tua juga ikut berpengaruh dalam meningkatkan kemampuan membaca siswa, hal ini dibuktikan dengan orang tua yang selalu mengajak anaknya untuk belajar di rumah.dan orang tua yang tidak mengalami kesulitan dalam mengajarkan anaknya membaca di rumah, serta orang tua yang selalu memberikan motivasi kepada anaknya untuk membaca. Serta dapat dibuktikan dengan orang tua yang mengajak anaknya ke toko buku untuk membelikan buku bacaan sesuai dengan keamuan siswa dan buku yang disukai siswa untuk dibaca siswa saat di rumah. Tetapi ada orang tua siswa yang pada saat kegiatan wawancara bercerita bahwa minat anaknya untuk membaca kurang anaknya yang susah diajari dan di ajak belajar kalau tidak sesuai dengan kemauan anaknya. Belajar membaca menulis kalau anaknya tidak mau dan dipaksa belajar selalu menagis, dan karena keadaan ekonomi kelauarga yang kurang jadi kedua orang tuanya sibuk bekerja dan tidak terlalau memantau anak dalam belajar.

Berdasarkan hasil dari penelitian, peneliti menganalisis bahwa faktor-faktor penghambat dalam membaca permulaan pada siswa kelas 1 SD Negeri 1 Wonorejo yaitu : (1). Faktor Intelektual mencakup tingkat kecerdasan anak yaitu kemampuan siswa yang rendah disbanding dengan teman-temannya sehingga siswa tersebut lamban dalam membaca dan mengalami kesulitan dalam mengikuti kegiatan pembelajaran, (2). Faktor lingkungan lingkungan keluarga juga menjadi salah satu faktor yang dapat mempengaruhi kemampuan mmebaca siswa, memcakup latar belakang dan pengalman siswa yang kurang, siswa sangat memerlukan keteladanan dalam membaca. Keteladanan tersebut harus ditunjukkan orang tua sesering mungkin.keadaan ekonomi keluarga yang rendah juga menyebabakan anak mengslami hambatan dalam membaca permulaan, (3). Motivasi, kurangnya motivasi dari pihak orang tua siswa untuk mendorng dan memberi semnagat untuk anaknya dalam membaca, (4).Minat, Kurangnya minat membaca siswa yang rendah menyebabkan tingkat keberhasilan anak dalam membaca sulit tercapai.

Penelitian juga mengungkapkan bahwa alternatif solusi untuk mengatasai kesulitan dalam membaca permulaan di sekolah dasar yaitu : (1). Guru kelas lebih memprioritaskan anak-anak yang mengalami hambatan atau kesulitan dalam membaca permulaan, (2). Guru kelas juga harus memberikan perhatian khusus kepada anak-anak yang mengalami kesulitan, (3). Hubungan kerjasama yang baik antara guru kelas dan orang tua siswa, (4). Orang tua harus lebih memperhatikan anaknya, (5). Minat siswa harus dikembangkan dan dilatih terus menerus.

\section{Simpulan dan Saran}

Berdasarkan hasil penelitian dan pembahasan peneliti menganalisis bahawa faktor-faktor penghambat membaca permulaan meliputi faktor intelektual, faktor lingkungan dan faktor psikologis serta alternative solusi untuk mengatasi kesulitan dalam membaca permulaan pada siswa kelas 1 SD Negeri 1 Wonorejo sebagai berikut : (1). Faktor Intelektual mencakup tingkat kecerdasan anak yaitu kemampuan siswa yang rendah disbanding dengan teman-temannya sehingga siswa tersebut lamban dalam membaca dan mengalami kesulitan dalam mengikuti kegiatan pembelajaran, (2). Faktor lingkungan lingkungan keluarga juga menjadi salah satu faktor yang dapat mempengaruhi kemampuan mmebaca siswa, memcakup latar belakang dan pengalman siswa yang kurang, siswa sangat memerlukan keteladanan dalam membaca. Keteladanan tersebut harus ditunjukkan orang tua sesering mungkin.keadaan ekonomi keluarga yang rendah juga menyebabakan anak mengslami hambatan dalam membaca permulaan, (3). Motivasi, kurangnya motivasi dari pihak orang tua siswa untuk mendorng dan memberi semnagat untuk anaknya dalam membaca, (4).Minat, Kurangnya minat membaca siswa yang rendah menyebabkan tingkat keberhasilan anak dalam membaca sulit tercapai. Dan alternatif solusi untuk mengatasai kesulitan dalam membaca permulaan di sekolah dasar yaitu : (1). Guru kelas lebih memprioritaskan anak-anak yang mengalami hambatan atau kesulitan dalam membaca permulaan, (2). Guru kelas juga harus memberikan perhatian khusus kepada anak-anak yang mengalami kesulitan, (3). 
Hubungan kerjasama yang baik antara guru kelas dan orang tua siswa, (4). Orang tua harus lebih memperhatikan anaknya, (5). Minat siswa harus dikembangkan dan dilatih terus menerus.

Saran yang diberikan peneliti merupakan saran yang berkaitan dengan perbaikan dan untuk meningkatkan kualitas pembelajaran yang dapat mengembangkan minat dan kemampuan siswa kelas rendah dalam keterampilan membaca. Bagi peneliti hasil dari penelitian ini mudah-mudahan dapat mendorong semangat penulis untuk terus berkarya, serta dapat menambah pengetahuan, pengalaman dan wawasan berfikir kritis guna melatih kemampuan dan menganalisis masalah-masalah pendidikan dan sebagai acuan bagi penulis untuk nantinya sebelum terjun dan mengajar di dunia pendidikan. Bagi peneliti selanjutnya penelitan ini diharapkan dapat digunakan sebagai bahan acuan untuk dikembangkan dan dilanjutkan oleh peneliti lain dengan bahasan yang lebih dalam dan lebih luas.

\section{Daftar Rujukan}

Abdurrahman, Mulyono. 2010. Pendidikan Bagi Anak Berkesulitan Belajar. Jakarta: Rineka Cipta.

Anantha, Md. Dhiah Dewi \& Kt. Pudjawan, Ni Md. Setuti. 2013. "Pengaruh Pembelajaran Tematik Berbantuan Permainan Meloncat Bulatan Kata Terhadap Kemampuan Membaca Permulaan Pada Mata Pelajaran Bahasa Indonesia Kelas I SD.

Antari, Ni Md. Tulus \& Ign. I Wyn. Suwatra, Ni Ngh. Madri Antari. 2013."Pengaruh Model Pembelajaran Jolly Phonics terhadap Kemampuan Membaca dan Menulis Permulaan Pada Mata Pelajaran Bahasa Indonesia Siswa Kelas I SD". Jurnal Mimbar PGSD Vol 1 No 12013 (48)

Arikunto, Suharsimi. 2010. Prosedur Penelitian Suatu Pendekatan Praktik. Jakarta: Rineka Cipta.

Ardi Wirata. 2016. Faktor Pendukung dan Penghambat Kemampuan Membaca Permulaan Murid Kelas II SDN Kraton Yogyakarta.Skripsi.Universitas Negeri Yogyakarta.

Darmiyati Zuchdi dan Budiasih.1997. Pendidikan Bahasa dan Sastra Indonesia di Kelas Rendah. Jakarta: Depdikbud.

Depdiknas. 2006. Peraturan Menteri Pendidikan Nasional No. 22 dan 23 tahun 2006 tentang Standar Isi dan Kompetensi Lulusan. Jakarta: Cipta Jaya.

Daryanto. 2013. Belajar dan Mengajar. Bandung: Yrama Widya.

Gusti NgurahOka, I.2005. Pengantar Membaca dan Pengajarannya. Surabaya: Usaha Nasional.

Henry Guntur Tarigan. 2008. Membaca sebagai Suatu Keterampilan Berbahasa.Bandung: Angkasa.

Kurtanto eko. 2013. Pembelajaran calistung. Jambi : One Production.

Moleong, Lexy J. 2007. Metode Penelitian Kualitatif. Bandung:PT. Remaja Rosda karya.

Munib, Achmad. 2012. Pengantar Ilmu Pendidikan. Semarang: Universitas Negeri Semarang Press.

Miles. B. Mathew dan Michael Huberman. 1992. Analisis Data Kualitatif Buku Sumber Tentang Metodemetode Baru. Jakarta:UIP.

Muzamiroh. 2013. Kupas Tuntas Kurikulum 2013 . Jakarta: Kata Pena.

Ngalim Purwanto. 2006. Prinsip-Prinsip dan Teknik Evaluasi Pengajaran. Bandung: Rosda Karya.

Farida Rahim. (2005). Pengajaran Membaca di Sekolah Dasar. Jakarta: Bumi Aksara.

Paramita, A.A.Ayu Trisna Pradnya \& Rini Kritstiantari, I Gd Meter. 2013. Penerapan Media Kartu Huruf Dalam Pembelajaran Bahasa Indonesia Untuk Meningkatkan Kemampuan Membaca Permulaan Siswa Kelas I Sd Negeri 1 Bunutin Bangli. Jurnal Mimbar PGSD Vol 1 No 12013 (68). 
Putra, Ida Bagus Made Eka Yoni Adnyana. 2017. “Penerapan Media Gambar dan Kartu Huruf Untuk Meningkatkan Keterampilan Membaca Permulaan". Journal of Education Action Research Volume 1 No. 2 Agustus 2017133 .

Rahim, Farida. 2011. Pengajaran Membaca di Sekolah Dasar. Jakarta: PT Bumi Aksara.

Rasna , I Wayan. 2010. "Metode Gasif Pengajaran Membaca Dan Penulisan : Sebuah Pemikiran”. Jurnal Pendidikan dan Pengajaran, Jilid 43, Nomor 16, Juli 2010, hlm.133 - 140

Rizkiana (2016).Analisis Kesulitan Membaca Permulaan Siswa Kelas I SD Negeri Bangunrejo 2 Kricak Tegalrejo Yogyakarta.Skripsi.Universitas Negeri Yogyakarta.

Robert S, Feldman (2012). Pengantar Psikologi: Understarding Psychology Edisi 10: Buku 2. Jakarta: Penerbit Salemba Humanika.

Slamet Suryanto. 2003 .Konsep Dasar Pendidikan Anak Usia Dini. Yogyakarta: Universitas Negeri Yogyakarta.

Solchan, dkk. 2009. Pendidikan Bahasa Indonesia di SD. Jakarta: Universitas Terbuka.

Sudiarta, I.W.2017. "Pengaruh Metode Jolly Phonics Terhadap Kemampuan Membaca Dan Menulis Permulaan Bahasa Inggris Pada Anak Kelompok B Tk Mahardika Denpasar". JIPP, Volume 1 Nomor 3 Okotober 2017 (240-251).

Sugiyono. 2014. Metode Penelitian Kombinasi (Mixed Methods). Bandung: Alfabeta.

Sugiyono.2012 .Metode Penelitian Pendidikan : Pendekatan Kuantitatif, Kualitatif, Dan R\&D. Bandung: Alfabeta.

Sumantri, Made \& Dewa Nyoman Sudana, I. B. Eka Yoni Adnyana P.2017. "Penerapan Media Gambar dan Kartu Huruf Untuk Meningkatkan Keterampilan Membaca Permulaan”. International Journal of Elementary Education. Vol.1 (1) pp. 1-10.

Syamsu, Yusuf. 2007. Psikologi Perkembangan Anak dan Remaja. Bandung: PT. Remaja Rosdakarya.

Tarigan, Henry Guntur.1984. Berbicara sebagai suatu keterampilan berbahasa, Bandung : Angkasa.

Zubaidah, Enny. 2013. Kesulitan Membaca Permulaan pada Anak Diagnosa dan Cara Mengatasinya. Yogyakarta: UNY 